\title{
Confrontation Naming and Verbal Fluency of Alzheimer's Disease and Vascular Dementia
}

\author{
Sun-Mi Lee', Soo-Ryon Kim², Jin-Dong Kim² \\ ${ }^{1}$ EDEN Language Psychology Development Institute, Busan, Korea \\ ${ }^{2}$ Department of Speech and Hearing Therapy, College of Health Science, Catholic University of Pusan, Busan, Korea
}

알츠하이머병과 혈관성 치매의 중증도에 따른 대면이름대기 능력과 어휘유창성

이선미 ${ }^{1} \cdot$ 김수련 $^{2} \cdot$ 김진동 $^{2}$

에덴 언어심리발달연구소', 부산가톨릭대학교 보건과학대학 언어청각치료학과 ${ }^{2}$

\begin{abstract}
Purpose: Alzheimer's disease (AD) and vascular dementia (VaD) are representative dementia types that account for more than $70 \%$ to $80 \%$ of all dementia. However, these two types of dementia have different deterioration patterns as dementia progresses. This study conducted confrontation naming and verbal fluency tasks among $\mathrm{AD}$ and $\mathrm{VaD}$ patients diagnosed as the mild or moderate stages. Methods: 20 patients with $A D$ ( 10 mild, 10 moderate), 20 patients with VaD (10 mild, 10 moderate), and 10 normal elderly persons performed the Korean version-Boston Naming Test and verbal fluency tasks (semantic and phonemic). Results: Patients with AD and VaD showed significantly lower performance in confrontation naming, semantic verbal fluency, and phonemic verbal fluency tasks than normal elderly persons. However, patients with AD demonstrated marked impairment in confrontation naming and semantic verbal fluency even in the mild stage, and showed a sharp deterioration in the course of the disease from the mild to moderate stage. On the other hand, patients with $\mathrm{VaD}$ revealed a significant decrease in phonemic verbal fluency from the mild stage. Conclusion: As a result, $\mathrm{AD}$ and VaD differ in their deterioration patterns as revealed by confrontation naming and verbal fluency tasks according to the progression of the disease. Therefore, it is possible to make a more accurate and early diagnosis regarding dementia subtypes by comparing the performance of confrontation naming, semantic and phonemic verbal fluency tasks. This may also be helpful in designing an effective intervention plan by predicting the impairment pattern.
\end{abstract}

Key Words: Alzheimer's disease, Vascular dementia, Severity, Confrontation naming, Verbal fluency.

Received: September 13, 2017 / Revised: September 27, 2017 / Accepted: September 30, 2017

Correspondence: Jin-Dong Kim, Department of Speech and Hearing Therapy, College of Health Science, Catholic University of Pusan, 57 Oryundae-ro, Geumjeong-gu, Busan 46252, Korea

Tel: +82-51-510-0844 / Fax: +82-51-510-0848 / E-mail: jdkim@cup.ac.kr

\section{INTRODUCTION}

치매는 원인 질환 및 진행 과정, 신경병리학적 소견에 따라 다양한 유형으로 분류되며(Brookshire \& McNeil, 2014), 그 유 형에 따라 진행되는 양상에 차이가 있다. 치매의 유형 중 가장 발생 빈도가 높은 알츠하이머병(Alzheimer's disease)은 퇴행 성 뇌 질환으로 인해 발병하여 서서히 퇴행되는 양상을 보인다 (Han, 2001). 알츠하이머병의 가장 두드러진 특징은 이름대기 장애로, 발병 초기부터 언어 하위 영역의 다른 능력들에 비해 심 각하게 손상된다(Bowles et al., 1987). 알츠하이머병 환자의 이 름대기 능력은 주로 대면이름대기(confrontation naming) 과제
를 통하여 살펴보았는데(Bentham et al., 1997; Bowles et al., 1987; Hodges et al., 1992; Vogle et al., 2005), 연구 결과 치매 집단이 일반 노인보다 이름대기 수행력이 유의하게 낮았다고 보 고하였다. 또한 치매가 악화되면서 의미 체계가 점진적으로 퇴 행되어 이름대기 능력의 손상 정도는 심해지며(Chenery et al., 1996), 반응은 더 적게 하는 반면 오류는 더 많이 산출되는 문 제들을 보였다(Bowles et al., 1987). 또한 약 8,300여 명의 알츠 하이머병 환자의 어휘유창성(verbal fluency) 능력을 메타 분석 한 연구(Henry et al., 2004)에 따르면 알츠하이머병 환자는 정 상인에 비해 어휘유창성 능력이 통계적으로 유의하게 낮았으 며, 특히 음소유창성(phonemic fluency)에 비해 의미유창성 
(semantic fluency)이 더 낮은 것으로 밝혀졌다. 그러나 이 연 구에서는 치매의 중증도(dementia severity)는 음소 및 의미유 창성 장애의 상대적인 크기와 유의한 관련이 없었다고 보고하 였다.

알츠하이머병에 이어 두 번째로 발생 빈도가 높은 혈관성 치 매(vascular dementia)는 기억장애와 더불어 다양한 영역의 인 지 기능장애를 보이며(Román, 2005), 뇌 손상 부위에 따라 그 예후가 달라진다. 단일 경색보다는 다발성 뇌경색에 의해 전두 엽 및 전두엽의 피질하(subcortical) 회로가 두드러지게 손상되 어 집행 기능, 주의집중, 어휘유창성 등의 영역에서 어려움을 보 인다(Kertesz \& Clydesdale, 1994). Lukatela et al.(1998)의 연 구에서 초기 알츠하이머병, 초기 혈관성 치매, 일반 노인 집단 간 이름대기 오류를 살펴본 결과, 두 유형의 치매 집단이 공통적 으로 일반 노인 집단에 비해 이름대기 능력이 낮았으나 두 치매 집단 간에는 차이가 없었음을 보고하였다. 반면 연령, 성별, 치매 중증도, 지능을 일치시킨 103 명의 알츠하이머병 집단과 68 명의 혈관성 치매 집단을 대상으로 신경심리검사의 수행력을 비교한 Baillon et al.(2003)은 연령과 교육 정도, 인지 및 일상생활 수행 력을 일치시킨 19명의 피질하 혈관성 치매와 알츠하이머병 환자 의 인지장애를 비교한 Graham et al.(2004)의 연구에서는 알츠 하이머병 환자의 이름대기 능력이 혈관성 치매 환자에 비해 유 의하게 더 손상되었다고 보고하였다.

알츠하이머병 환자는 병이 진행됨에 따라 지속적이고 점진적 인 신경심리학적 결함을 나타내는 반면(Kim et al., 1997), 혈관 성 치매는 비교적 급작스럽게 발병되어 계단식으로 저하되는 양상을 보인다. 따라서 전체 치매의 $70 \%$ 를 넘게 차지하고 있는 알츠하이머병과 혈관성 치매 환자는 이름대기 능력의 손상에 있어 차이를 보일 수도 있다. 즉, 치매는 질병이 진행함에 따라 퇴행되는 양상을 보이므로(Groves et al., 2000), 치매의 중증도 에 따라 이름대기 능력의 손상은 다른 양상을 보일 수 있으므 로 치매의 진단과 중재 과정에서 치매의 유형뿐 아니라 중등도 도 중요하게 고려해야 한다.

이름대기 능력을 평가하기 위하여 임상 및 연구 분야에서 가 장 광범위하게 활용되고 있는 두 가지 검사는 대면이름대기와 생성이름대기 과제이다. 대면이름대기 과제는 의미 체계 손상이 있는 경우 이름대기 장애를 가장 잘 보여준다(Friedman et al., 1992; Snyder et al., 1996). 생성이름대기는 어휘유창성 과제를 통해 평가되는데 의미 범주와 음소 범주로 구분된다. 이 두 하 위 과제는 서로 다른 정신 활동(mental activity)과 신경학적 네 트워크(neural network)를 사용한다(Birn et al., 2010; Laisney et al., 2009). 의미 범주 유창성 과제는 의미 기억(semantic memory)과 밀접한 관계가 있는 측두엽과 관련이 있고, 음소 범주 유창성 과제는 어휘-음운 기억(lexical-phonemic mem- ory)과 관계가 있는 전두엽과 관련이 있다고 보고되고 있다 (Baldo et al., 2006; Birn et al., 2010; Hodges et al., 1992).

따라서 이름대기 능력은 치매의 두 하위 유형의 언어능력 차 이를 가장 잘 확인할 수 있는 방법 중 하나로 추측된다. 이렇듯 대표적인 치매의 하위 유형인 알츠하이머병과 혈관성 치매는 질 병이 진행됨에 따라 관찰되는 언어능력의 변화에 차이가 발생 할 수 있다. 특히 치매의 유형뿐 아니라 동일 유형의 치매라 할 지라도 중증도에 따라서 이름대기 능력의 손상에 있어 차이가 존재할 것으로 예상된다. 그러나 혈관성 치매의 발병률이 높음 에도 불구하고 대부분의 치매 연구는 알츠하이머병을 중심으 로 이루어져서 혈관성 치매에 대한 선행 연구가 미흡한 실정이 다. 또한 기존의 선행연구에서는 중증도에 따른 알츠하이머병 과 혈관성 치매 환자의 이름대기 능력을 비교한 연구는 거의 이 루어지지 않은 실정이다.

본 연구는 치매 유형 및 중증도에 따른 언어 특성 및 차이를 이해하고, 적절한 치료 계획을 수립하는 데 기초 자료로 활용 할 수 있도록 치매의 유형 중 가장 대표적인 알츠하이머병과 혈 관성 치매 환자를 경도(mild)와 중등도(moderate)로 분류하여, 중증도 또는 치매 진행에 따른 대면이름대기 및 이휘유창성 능 력의 손상 양상의 차이를 살펴보고자 하였다.

\section{MATERIALS AND METHODS}

\section{연구 대상}

연구 대상자는 부산 소재의 병원 및 치매 요양원에 입원 또는 거주하고 있는 환자들 가운데 신경과 전문의로부터 진단받은 알츠하이머병 환자 20 명(경도 10 명, 중등도 10 명), 혈관성 치매 환자 20명(경도 10 명, 중등도 10 명)과 일반 노인 10명, 총 50 명이 었다. 본 연구에서 알츠하이머 및 혈관성 치매 환자의 중증도는 한국형 전반적 퇴화척도(Global Deterioration Scale, GDS) (Choi et al., 2002)를 기준으로 분류하였으며, 경도 치매와 중 등도 치매는 각각 이 척도의 5 단계(초기 중증의 인지장애 또는 초기 치매)와 6 단계(중증의 인지장애 또는 중기 치매)의 기준에 부합되는 환자를 선정하였다. 간이정신상태검사(Mini-Mental State Examination, MMSE)는 전 세계적으로 널리 사용되고 있는 치매 선별 도구로 비교적 짧은 시간 내에 시행할 수 있고 중 증도와 중증 치매 환자의 선별에 신뢰도와 타당도가 입증되어 우리나라에서는 한국판 간이정신상태검사인 Korean Version of Mini-Mental State Examination (MMSE-K) (Park \& Kwon, 1989)과 Korean Mini-Mental State Examination (K-MMSE) (Kang et al., 1997)라는 두 가지 종류가 표준화되어 임상 현장에 서 사용되고 있다(Kang, 2006; Park \& Kwon, 1989). MMSE$\mathrm{K}$ 는 MMSE 원본 내용을 부분적으로 개정한 것으로 절단점을 
23점으로 이용하는 데 반해, K-MMSE는 원본 문항을 그대로 유지하여 제작되었다. 특히 K-MMSE의 노인 규준에 대한 연 구(Kang, 2006)를 살펴보면 연구 대상자들의 평균 교육 연수와 연령에 따른 정상 규준을 제시하고 있다. 본 연구의 일반 노인 집단은 정신과적·신경과적·내과적 질환을 않고 있지 않으며, $\mathrm{MMSE}-\mathrm{K}$ 의 점수가 24점 이상의 기준으로 선정하였다.

일반 노인과 네 개의 치매 집단은 성별 $\left[\mathrm{F}_{(1,48)}=0.453, p=\right.$ $0.504]$ 및 연령 $\left[\mathrm{F}_{(1,48)}=1.425, p=0.247\right]$, 교육 연수 $\left[\mathrm{F}_{(1,48)}=0.433\right.$, $p=0.730]$ 에 유의한 차이가 없었다. 대상자에 대한 정보는 Table 1 과 같다.

\section{검사 도구}

본 연구에서는 대상자의 대면이름대기 능력을 평가하기 위해 한국판 보스톤 이름대기검사(Korean version-Boston Naming Test, K-BNT) (Kim \& Na, 1997)를 실시하였다. 그리고 어휘 유창성을 평가하기 위해 서울신경심리검사(Seoul Neuropsychological Screening Battery) (Kang \& Na, 2003)에 포함되어 있는 동물 범주에 대한 의미유창성 과제와 ㄱ. ㄱㅅㅇㅔ 대한 음 소유창성 과제를 실시하였다.

\section{연구 절차}

본 연구의 진행에 앞서 부산가톨릭대학교 기관생명윤리위원 회(Institute Review Board, IRB)의 승인을 받았다(승인번호: CUPIRB-2015-058). 또한 실험을 진행하기 전에 모든 대상자 와 보호자들은 연구의 목적, 진행 절차 등에 대한 충분한 설명 을 제공받았으며 모든 대상자들로부터 동의서를 취득하였다. 모든 검사는 주변 소음에 의해 방해를 받지 않고 집중할 수 있 도록 통제된 장소에서 연구자 1 인에 의해 개별적으로 진행되었 다. K-BNT 실시 시 모든 대상자의 반응은 검사 기록지에 즉시
기록하였다. 어휘유창성검사는 대부분의 대상자들이 음소 단서 보다는 의미 단서를 더 쉽게 느낀다는 선행연구(Martin \& Fedio, 1983)에 근거하여, 대상자들이 어려운 과제에 좌절을 느껴서 검사를 포기할 가능성을 사전에 차단하기 위해 의미유창성 과 제를 먼저 실시한 후, 음소유창성 과제를 실시하였다. 대면이름 대기 과제의 점수는 정반응한 문항의 개수이며, 어휘유창성 과 제의 점수는 범주 및 음소에 맞게 산출된 어휘의 개수이다.

\section{신뢰도 분석}

전체 대상자(총 50 명)의 $20 \%$ 에 해당하는 10 명의 자료를 무작 위로 추출하여 본 연구자 이외에 임상 경력이 5년 이상인 2급 언어 재활사에게 평가하도록 하였다. 대면이름대기 과제와 어 휘유창성 과제의 점수에 대한 평가자 간 신뢰도는 $100 \%$ 로 나 타났다.

\section{통계 처리}

본 연구의 통계 분석은 PASW Statistics 18 프로그램(IBM Corp., Armonk, NY, USA)을 이용하였다. 일반 노인 집단, 경도 알츠하이머병 환자 집단, 중등도 알츠하이머병 환자 집단, 경도 혈관성 치매 환자 집단, 중등도 혈관성 치매 환자 집단 간의 과제 수행 능력의 차이를 알아보기 위하여 일원분산분석(one wayANOVA)을 실시한 후 Scheffe 방식으로 사후 검정하였다.

\section{RESULTS}

\section{알츠하이머병, 혈관성 치매, 일반 노인의 대면이름대기 능력 비교}

집단 간 대면이름대기 과제의 평균 수행 능력을 비교한 결과 일반 노인의 평균은 $47.60[$ standard deviation $(\mathrm{SD})=7.49$ ], 경

Table 1. Demographic information of participants

\begin{tabular}{lccccc}
\hline Demographic information & $\mathrm{NE}(\mathrm{n}=10)$ & $\mathrm{AD} 1(\mathrm{n}=10)$ & $\mathrm{AD} 2(\mathrm{n}=10)$ & $\mathrm{VaD} 1(\mathrm{n}=10)$ & $\mathrm{VaD} 2(\mathrm{n}=10)$ \\
\hline Gender $(\mathrm{M} / \mathrm{F})$ & $7 / 3$ & $9 / 1$ & $7 / 3$ & $8 / 2$ & $6 / 4$ \\
Age (year) & 72.4 & 69.4 & 69.2 & 68.8 & 69.3 \\
Education (year) & 9.6 & 9.8 & 9.2 & 9.8 & 9.2 \\
\hline
\end{tabular}

NE: normal elderly, AD1: mild Alzheimer's disease, AD2: moderate Alzheimer's disease, VaD1: mild vascular dementia, VaD2: vascular dementia, M: male, F: female

Table 2. Results of ANOVA and post-hoc analysis of confrontation naming task between groups

\begin{tabular}{lccccc}
\hline \multicolumn{1}{c}{ Factor } & SS & df & MS & F-value & Scheffe \\
\hline Between groups & $3,806.080$ & 4 & 951.520 & $41.358^{*}$ & $\mathrm{a}>\mathrm{b}, \mathrm{c}, \mathrm{d}, \mathrm{e}$ \\
Within group & $1,035.300$ & 45 & 23.007 & $\mathrm{~b}>\mathrm{c}, \mathrm{d}, \mathrm{e}$ & $\mathrm{c}>\mathrm{d}, \mathrm{e}$ \\
Total & $4,841.380$ & 49 & & $\mathrm{~d}>\mathrm{e}$ \\
\hline
\end{tabular}

${ }^{*} p<0.05$. a: normal elderly, b: mild Alzheimer's disease, c: moderate Alzheimer's disease, d: mild vascular dementia, e: vascular dementia, SS: sums of squares, df: degree of freedom, MS: mean squares 
도 혈관성 치매 집단의 평균은 $40.50(\mathrm{SD}=3.54)$, 경도 알츠하 이머병 집단의 평균은 $33.60(\mathrm{SD}=3.84)$, 중등도 혈관성 치매 집단의 평균은 $32.80(\mathrm{SD}=4.44)$, 중등도 알츠하이머병 집단의 평균은 $21.40(\mathrm{SD}=3.47)$ 의 순으로 나타났다. 일원분산분석을 실시한 결과 대면이름대기 능력에 있어 집단 간 유의한 차이 $\left[\mathrm{F}_{(4,45)}=41.358, p<0.05\right]$ 가 나타났다. 사후 검증을 실시한 결 과 일반 노인 집단은 모든 치매 집단과 유의한 차이를 보였다. 경도 알츠하이머병 집단은 중등도 알츠하이머병, 경도 혈관성 치매, 중등도 혈관성 치매 집단과 유의한 차이가 있었다. 중등 도 알츠하이머병 집단은 경도 혈관성 치매, 중등도 혈관성 치매 집단과 유의한 차이를 보였으며, 경도 혈관성 치매 집단은 중등 도 혈관성 치매 집단과 유의한 차이를 보였다. 이에 따른 일원 분산분석 및 사후 검증의 결과는 Table 2 와 같다.

\section{알츠하이머병, 혈관성 치매, 일반 노인의 의미유창성 비교}

집단 간 의미유창성 능력을 비교한 결과 일반 노인의 평균은 $13.00(\mathrm{SD}=2.87)$, 경도 혈관성 치매 집단의 평균은 $9.00(\mathrm{SD}=$ $1.63)$, 경도 알츠하이머병 집단의 평균은 $8.30(\mathrm{SD}=3.20)$, 중등 도 혈관성 치매 집단의 평균은 $8.20(\mathrm{SD}=1.48)$, 중등도 알츠하 이머병 집단의 평균은 $4.70(\mathrm{SD}=2.11)$ 의 순으로 나타났다. 일 원분산분석을 실시한 결과 의미유창성 능력에 있어 집단 간 유 의한 차이 $\left[\mathrm{F}_{(4,45)}=15.750, p<0.05\right]$ 가 나타났다. 사후 검증을 실시한 결과 일반 노인 집단과 모든 치매 집단 간의 유의한 차이 가 나타났다. 경도 알츠하이머병 집단은 중등도 알츠하이머병 집단과 유의한 차이를 보였다. 중등도 알츠하이머병 집단은 경 도 혈관성 치매, 중등도 혈관성 치매 집단과 유의한 차이를 보였 으며, 경도 혈관성 치매 집단은 중등도 혈관성 치매 집단과 유 의한 차이를 보였다. 이에 따른 일원분산분석 및 사후 검증의 결과는 Table 3과 같다.

\section{알츠하이머병, 혈관성 치매, 일반 노인의 음소유창성 비교}

집단 간 음소유창성 능력을 비교한 결과 일반 노인의 평균은 $11.40(\mathrm{SD}=2.76)$, 경도 알츠하이머병 집단의 평균은 $8.20(\mathrm{SD}=$ $1.93)$, 중등도 알츠하이머병 집단의 평균은 $7.20(\mathrm{SD}=1.93)$, 경 도 혈관성 치매 집단의 평균은 $4.90(\mathrm{SD}=1.10)$, 중등도 혈관성 치매 집단의 평균은 $3.40(\mathrm{SD}=1.71)$ 의 순으로 나타났다. 일원분 산분석을 실시한 결과 음소유창성 능력에 있어 집단 간 유의한 차이 $\left[\mathrm{F}_{(4,45)}=24.861, p<0.05\right]$ 가 나타났다. 사후 검증을 실시한 결과 일반 노인 집단과 모든 치매 집단 간의 유의한 차이가 나타 났다. 경도 알츠하이머병 집단은 경도 혈관성 치매, 중등도 혈관 성 치매 집단과 유의한 차이를 보였으며, 중등도 알츠하이머병 집단은 중등도 혈관성 치매 집단과 유의한 차이를 보였다. 이에 따른 일원분산분석 및 사후 검증의 결과는 Table 4 와 같다.

\section{DISCUSSIONS}

우리나라 임상 현장에 치매의 중증도를 평가하기 위해 사용 되는 대표적인 도구는 한국형 확장판 임상치매평가척도(Expanded Clinical Dementia Rating, CDR) (Choi et al., 2001)와 한국형 전반적퇴화척도(GDS) (Choi et al., 2002)가 있다. CDR 은 치매선별검사가 아니라 알츠하이머병 환자의 전반적인 인지 사회적 기능을 평가하기 위해 개발되어 치매의 중증도를 평가 할 수 있으며(Hughes et al., 1982; Morris, 1993), 확장판의 경우 치매의 중증도를 0 5점 척도로 평가한다. CDR 0은 치매가 아니 며, $\mathrm{CDR} 0.5$ 는 치매가 의심스러운 경우이고, $\mathrm{CDR} 1$ 은 경도 치 매, $\mathrm{CDR} 2$ 는 중등도 치매, $\mathrm{CDR} 3$ 는 고도(severe) 치매, $\mathrm{CDR} 4$ 는 심도(profodund) 치매, CDR 5는 말기(terminal) 치매를 뜻 한다. 기억력 및 일상생활 기능 중심의 평가 척도인 GDS 또한, 퇴행성 치매의 치매 중증도를 평가할 수 있다(Reisberg et al.,

Table 3. Results of ANOVA and post-hoc analysis of semantic verbal fluency task between groups

\begin{tabular}{|c|c|c|c|c|c|}
\hline Factor & SS & df & MS & F-value & Scheffe \\
\hline Between groups & 349.720 & 4 & 87.430 & $15.750^{*}$ & $a>b, c, d, e$ \\
\hline Within group & 249.800 & 45 & 5.551 & & $\begin{array}{l}b>c \\
c>d, e\end{array}$ \\
\hline Total & 599.520 & 49 & & & $\mathrm{~d}>\mathrm{e}$ \\
\hline
\end{tabular}

${ }^{*} p<0.05$. a: normal elderly, b: mild Alzheimer's disease, c: moderate Alzheimer's disease, d: mild vascular dementia, e: vascular dementia, SS: sums of squares, df: degree of freedom, MS: mean squares

Table 4. Results of ANOVA and post-hoc analysis of phonemic verbal fluency task between groups

\begin{tabular}{lcrrrr}
\hline \multicolumn{1}{c}{ Factor } & SS & df & MS & F-value & Scheffe \\
\hline Between groups & 382.080 & 4 & 95.520 & $24.861^{*}$ & $\mathrm{a}>\mathrm{b}, \mathrm{c}, \mathrm{d}, \mathrm{e}$ \\
Within group & 172.900 & 45 & 3.842 & & $\mathrm{~b}>\mathrm{d}, \mathrm{e}$ \\
Total & 554.980 & 49 & & $\mathrm{c}>\mathrm{e}$ & \\
\hline
\end{tabular}

${ }^{*} p<0.05$. a: normal elderly, b: mild Alzheimer's disease, c: moderate Alzheimer's disease, d: mild vascular dementia, e: vascular dementia, SS: sums of squares, df: degree of freedom, MS: mean squares 
1982). 특히 GDS는 치매가 의심되는 환자나 치매로 진행된 환 자의 임상 양상 및 심각도를 7단계로 평가하며 시간 경과에 따 른 환자의 변화를 파악할 수 있어서 초기 인지장애의 평가에 $\mathrm{CDR}$ 보다 우수하다고 알려져 있다. 41 명의 알츠하이머병 환자, 37 명의 혈관성 치매 환자, 34 명의 정상 노인을 대상으로 한국판 GDS의 타당도를 검증한 Choi et al.(2002)에 따르면 GDS 5단 계는 $\mathrm{CDR} 1$ 또는 $2, \mathrm{GDS}$ 6단계는 $\mathrm{CDR} 2$ 또는 3에 해당하였 다. 상기 두 척도 모두 치료의 경과나 예후를 평가하는 데 유용 하게 사용할 수 있으나 기억장애를 주 증상으로 하는 퇴행성 치매(예, 알츠하이머병)를 위해 개발된 도구이므로 초기에 전두 엽의 기능저하가 나타나는 혈관성 치매에는 적합하지 않을 수 있다(Padovani et al., 1995). 이러한 제한점에도 불구하고 혈관 성 치매를 포함한 다양한 치매 연구에 사용되고 있다.

본 연구에서는 치매의 유형 중 가장 대표적인 알츠하이머병과 혈관성 치매 환자의 중증도를, GDS를 기준으로 경도 치매(GDS 5단계) 및 중등도 치매(GDS 6단계)로 구분하여 대면이름대기 능력과 어휘유창성을 살펴보았다. 우선, 한국판 보스톤 이름대 기검사(K-BNT)를 실시하여 대면이름대기 능력을 살펴본 결 과, 알츠하이머병과 혈관성 치매 두 집단 모두 일반 노인에 비 해 대면이름대기 능력이 유의하게 낮았다. 뿐만 아니라 GDS 분 류상 동일한 중증도를 가진 환자군 내에서 알츠하이머병 환자 는 혈관성 치매 환자에 비해 대면이름대기 능력이 크게 손상되 었다. 이러한 특징은 알츠하이머병과 혈관성 치매 환자를 대상 으로 대면이름대기 능력을 연구한 다수의 선행연구 및 결과와 일치한다(Baillon et al., 2003; Graham et al., 2004; Lukatela et al., 1998; Reiter, 2000). 특히 본 연구는 경도와 중등도의 다 른 중증도를 보이는 치매 집단을 대상으로 하였기 때문에 치매 의 진행에 따른 대면이름대기 능력의 손상 양상을 살펴볼 수 있었다. 알츠하이머병은 K-BNT의 점수가 경도의 경우 33.60 점 에서 중등도 21.40 점으로 12.20 점이 감소하였으나, 혈관성 치매 는 K-BNT 점수가 경도의 경우 40.50점에서 중등도 32.80점으 로 7.7점만 하락하였다. 결국 알츠하이머병은 병이 진행됨에 따 라 대면이름대기 능력이 급격하게 손상되는 것을 알 수 있었다. 이러한 특성은 중증도에 따른 알츠하이머병 환자의 이름대기 수행력을 비교한 선행연구(Chenery et al., 1996)의 결과와도 일 치한다. 또한 Baillon et al.(2003)의 연구에 의하면, 이름대기 과 제에서 혈관성 치매 집단이 알츠하이머병 집단보다 전반적으로 수행력이 더 좋은 것으로 나타나서 혈관성 치매 집단의 언어 기 능이 비교적 덜 손상되어 있다고 보고하였다.

다음으로 치매 환자를 대상으로 의미유창성을 살펴본 여러 선 행연구(Bentham et al., 1997; Choi, 2008)와 같이, 본 연구에서 도 알츠하이머병과 혈관성 치매 환자 모두 일반 노인에 비해 낮 은 의미유창성을 보였다. 뿐만 아니라 치매가 진행됨에 따라 의
미유창성 손상은 더욱 심화되는데, 그 손상 정도는 혈관성 치 매에 비해 알츠하이머병이 더욱 심각하였다. 혈관성 치매가 경 도의 경우 9.00 점에서 중등도 8.20점으로 1점도 채 안 되는 경미 한 변화를 보인 반면, 알츠하이머병은 경도의 경우 8.30점에서 중등도 4.70점으로 약 3.60점이라는 큰 점수 하락을 보였다. Canning et al.(2004)의 연구에 따르면 알츠하이머병은 의미 기 억의 손상이 초기부터 두드러지므로 의미 범주 어휘유창성 과 제의 수행력 저하가 뚜렷하게 나타난다고 하였다. 본 연구에서 는 알츠하이머병과 혈관성 치매는 치매 초기 단계(경도)에서는 의미유창성에 큰 차이가 없었으나(8.30점 vs. 9.00점), 치매가 진행된 중등도 단계에서는 혈관성 치매는 의미유창성이 저하 되는 속도가 더딘 반면 알츠하이머병은 매우 빠른 퇴행 속도를 보였다. 이는 경중 및 중등도 알츠하이머병 환자를 대상으로 한국어를 이용한 언어유창성의 변화를 2년 동안 종적으로 분 석한 연구(Lee et al., 2011)에서 의미유창성 점수는 추적기간 동안 통계적으로 유의미하게 악화되는 반면, 음소유창성 점수 는 의미 있는 변화가 없었다는 결과와 일치한다. 의미유창성은 주로 의미 기억을 반영하지만, 그 외 주의집중, 작업 기억, 수행 능력 및 재생 기능과 같은 다양한 인지능력들이 함께 연관되어 있을 것으로 추측되므로(Lee et al., 2011), 의미유창성과 관련이 있는 인지 기능들은 알츠하이머병의 초기 단계부터 손상될 수 있음을 시사한다. 이러한 차이는 알츠하이머병의 경우 초기부터 의미기억을 담당하는 측두엽의 신경병리학적 손상으로 인해 어 휘와 연관된 의미론적 지식 및 의미 기억 자체가 손상되기 때문 에 의미유창성이 크게 손상되지만, 혈관성 치매는 의미 기억 자 체의 문제라기보다는 의미 기억에 저장된 어휘 목록들 중 적절 한 어휘를 선택하여 인출하는 과정상의 문제에 기인하기 때문 이다(Chertkow \& Bub, 1990).

마지막으로 치매 집단은 대면이름대기와 의미유창성과 마찬 가지로 음소유창성에서도 일반 노인에 비해 낮은 능력을 보였으 며, 많은 선행연구들(Bentham et al., 1997; Graham et al., 2004; Vogel et al., 2005)이 이러한 결과를 지지한다. 그러나 중 증도에 따른 치매 집단의 음소유창성 손상 양상은 대면이름대 기 및 의미유창성과 상이하였다. 첫째, 음소유창성의 경우 중증 도에 상관없이 경도와 중등도 알츠하이머병 환자(8.20점, 7.20 점)는 경도의 혈관성 치매 환자(4.90점)보다 높은 점수를 획득 하였다. 결국 혈관성 치매는 치매 초기 단계에서부터 음소유창 성이 급격하게 저하된다는 것을 확인할 수 있었다. Reed et al.(2007)의 연구에 따르면 혈관성 치매 환자는 알츠하이머병에 비해 집행 기능 손상이 두드러져 음소유창성 과제 수행에 어려 움을 보인다고 하였다. 또한 양전자방출단층촬영을 이용하여 어휘유창성 검사 동안 활성화되는 정상인의 뇌 영역을 비교한 연구에 따르면(Gourovitch et al., 2000) 의미유창성 및 음소유 
창성 검사 모두 활성 뇌 영역이 비슷하게 나타났으나, 의미유창 성검사의 경우 상대적으로 측두엽이 가장 활성화되었고, 음소 유창성검사의 경우 상대적으로 전두엽 및 측두-두정엽이 더욱 활성화되는 것으로 밝혀졌으므로 의미유창성 과제는 측두엽과 관련이 있고, 음소유창성 과제는 전두엽과 좀 더 밀접한 관련 이 있을 것으로 추측된다. 또한 건강한 대조군과 비교하여 알 츠하이머형 치매 환자의 음소 및 의미유창성 능력의 손실 정도 를 비교하기 위해 153 개의 연구에 대해 메타 분석을 수행한 연 구(Henry et al., 2004)에 따르면 국소적인 전두엽 피질 병변 환 자의 경우는 발견되지 않지만 국소적인 측두엽 피질 병변 환자 에서는 발견되는 것처럼 알츠하이머형 치매 환자는 음소유창성 과제에 비해 의미 유창성 과제에서 좀 더 유의하게 손상받았다. 이는 음운 및 의미유창성은 인출 노력(effortful retrieval)과 같 은 집행 제어 과정(executive control processes)과 필적하는 요 구를 부과하는 것으로 생각되지만, 의미유창성은 상대적으로 의미론적 기억의 무결성에 더 의존적이며 이러한 결과는 알츠 하이머병의 의미론적 기억력의 결손이 의미적 저장 능력의 퇴화 를 반영하고 있음을 시사한다. 또한 인출 노력에서 최소한의 요 구만이 부과되는 대면이름대기, 의미론적 기억의 측정이 음소 유창성보다 좀 더 유의하게 손상받았다는 것이 이러한 결론을 지지한다고 주장하였다. 그러나 의미유창성은 또한 대면이름대 기보다 좀 더 유의하게 손상받았기 때문에 의미론적 기억 및 인출 노력의 결손이 부가적으로 추가되어 있을 수도 있을 것으 로 추측된다. 알츠하이머형 치매에서 의미론적 기억력의 결손 은 감별점으로 인정되지만, 음소유창성으로 색인된 집행 기능 저하는 질병 고유의 부가적인 특성을 구성하지는 않는다.

본 연구의 결과를 종합하여 보면, 알츠하이머병은 초기 단계 에서부터 의미론적 지식 및 의미 기억과 밀접한 연관이 있는 대 면이름대기와 의미유창성 과제에서 어려움을 보이며 치매가 진 행됨에 따라 급격한 능력 저하를 보인다. 그러나 혈관성 치매는 집행 기능 등과 같은 전두엽 및 전두엽 피질하 회로와 밀접한 연관이 있는 음소유창성이 치매 초기 단계에서부터 심각한 손 상을 보였다. 따라서 치매의 조기 진단이 중요한 초기 단계에서 는 대면이름대기, 의미유창성, 음소유창성의 손상 정도를 비교 하여 보다 정확한 진단이 가능하며 퇴행 양상을 예측하여 구체 적인 중재 계획을 설계할 수 있을 것이라 생각된다. 각 치매 집 단의 대상자 수가 충분하지 않고 종단 연구가 아닌 횡단 연구로 치매의 변화 양상을 살펴보았고, 일반 노인 대상자의 교육 연수 에 따른 K-MMSE의 최신 규준(Kang, 2006)을 적용하지 못한 제한점에도 불구하고, 본 연구는 알츠하이머병 위주로 진행되 었던 치매 환자의 언어능력 연구에 혈관성 치매 환자를 포함시 키고 경도 및 중등도에 따른 변화 양상을 살펴보았다는 점에서 의의가 있다.
중심 단어 : 알츠하이머병·혈관성 치매·중증도·대면이름대기· 어휘유창성.

\section{Acknowledgments}

This article was based on the first author's master's thesis from Catholic University of Pusan (2016).

\section{REFERENCES}

Baillon, S., Muhommad, S., Marudkar, M., Suribhatla, S., Dennis, M., Spreadbury, C., et al. (2003). Neuropsychological performance in Alzheimer's disease and vascular dementia: comparisons in a memory clinic population. International Journal of Geriatric Psychiatry, 18(7), 602-608.

Baldo, J. V., Schwartz, S., Wilkins, D., \& Dronkers, N. F. (2006). Role of frontal versus temporal cortex in verbal fluency as revealed by voxelbased lesion symptom mapping. Journal of the International Neuropsychological Society, 12(6), 896-900.

Bentham, P. W., Jones, S., \& Hodges, J. R. (1997). A comparison of semantic memory in vascular dementia and dementia of Alzheimer's type. International Journal of Geriatric Psychiatry, 12(5), 575-580.

Birn, R. M., Kenworthy, L., Case, L., Caravella, R., Jones, T. B., Bandettini, P. A., et. al. (2010). Neural systems supporting lexical search guided by letter and semantic category cues: a self-paced overt response fMRI study of verbal fluency. Neuroimage, 49(1), 1099-1107.

Bowles, N. L., Obler, L. K., \& Albert, M. L. (1987). Naming errors in healthy aging and dementia of the Alzheimer type. Cortex, 23(3), 519-524.

Brookshire, R. H. \& McNeil, M. R. (2014). Introduction to Neurogenic Communication Disorders-E-Book. (8th Ed.). (pp. 345-387). St. Louis, MO: Elsevier Health Sciences.

Canning, S. J., Leach, L., Stuss, D., Ngo, L., \& Black, S. E. (2004). Diagnostic utility of abbreviated fluency measures in Alzheimer disease and vascular dementia. Neurology, 62(4), 556-562.

Chenery, H. J., Murdoch, B. E., \& Ingram, J. C. L. (1996). An investigation of confrontation naming performance in Alzheimer's dementia as a function of disease severity. Aphasiology, 10(5), 423-441.

Chertkow, H. \& Bub, D. (1990). Semantic memory loss in Alzheimer-type dementia. In M. F. Schwartz. (1st ed). Issues in the Biology of Language and Cognition. Modular Deficits in Alzheimer-Type Dementia (pp. 207244). Cambridge, MA: The MIT Press.

Choi, H. J. (2008). A comparison of the performances of confrontation naming test and verbal fluency task in patients with prodromal Alzheimer's disease and mild Alzheimer's disease. Speech Science, 15(2), 111-118.

Choi, S. H., Na, D. L., Lee, B. H., Hahm, D. S., Jeong, J. H., Jeong, Y., et al. (2002). The Validity of the Korean Version of Global Deterioration Scale. Journal of the Korean Neurological Association, 20(6), 612-617.

Choi, S. H., Na, D. L., Lee, B. H., Hahm, D. S., Jeong, J. H., Yoon, S. J., et al. (2001). Estimating the validity of the Korean version of expanded Clinical Dementia Rating (CDR) Scale. Journal of the Korean Neurological Association, 19(6), 585-591.

Friedman, R. B., Ferguson, S., Robinson, S., \& Sunderland, T. (1992). Dissociation of mechanisms of reading in Alzheimer's disease. Brain and Language, 43(3), 400-413.

Gourovitch, M. L., Kirkby, B. S., Goldberg, T. E., Weinberger, D. R., Gold, J. M., Esposito, G., et al. (2000). A comparison of rCBF patterns during letter and semantic fluency. Neuropsychology, 14(3), 353-360.

Graham, N. L., Emery, T., \& Hodges, J. R. (2004). Distinctive cognitive profiles in Alzheimer's disease and subcortical vascular dementia. Journal of Neurology, Neurosurgery and Psychiatry, 75(1), 61-71.

Groves, W. C., Brandt, J., Steinberg, M., Warren, A., Rosenblatt, A., Baker, A., et. al. (2000). Vascular dementia and Alzheimer's disease: is there a difference? A comparison of symptoms by disease duration. The Journal of neuropsychiatry and Clinical Neurosciences, 12(3), 305-315.

Han, S. H. (2001). A newer therapeutic strategies for Alzheimer's disease. 
Journal of the Korean Neurological Association, 19(6), 559-565.

Henry, J. D., Crawford, J. R., \& Phillips, L. H. (2004). Verbal fluency performance in dementia of the Alzheimer's type: a meta-analysis. Neuropsychologia, 42(9), 1212-1222.

Hodges, J. R., Salmon, D. P., \& Butters, N. (1992). Semantic memory impairment in Alzheimer's disease: failure of access or degraded knowledge? Neuropsychologia, 30(4), 301-214.

Hughes, C. P., Berg, L., Danziger, W. L., Coben, L. A., \& Martin, R. L. (1982). A new clinical scale for the staging of dementia. The British Journal of Psychiatry, 140, 566-572.

Kang, Y. W. (2006). A Normative Study of the Korean-Mini Mental State Examination (K-MMSE) in the elderly. Korean Journal of Psychology: General, 25(2), 1-12.

Kang, Y. \& Na, D. L. (2003). Seoul Neuropsychological Screening Battery (SNSB). (1st ed). Seoul: Human Brain Research \& Consulting Co.

Kang, Y., Na, D. L., \& Hahn, S. (1997). A validity study on the Korean MiniMental State Examination (K-MMSE) in dementia patients. Journal of the Korean Neurological Association, 15(2), 300-308.

Kertesz, A. \& Clydesdale, S. (1994). Neuropsychological deficits in vascular dementia vs Alzheimer's disease. Frontal lobe deficits prominent in vascular dementia. Archives of Neurology, 51(12), 1226-1231.

Kim, H., Kim, E. Y., \& Na, D. L. (1997). Naming deficits in patients with dementia of the Alzheimer type: Error analysis of Korean version-Boston naming test. Journal of the Korean Neurological Association, 15(5), 10121021.

Kim, H. \& Na, D. L. (1997). Korean version-Boston Naming Test (K-BNT). Seoul: Hakjisa.

Laisney, M., Matuszewski, V., Mézenge, F., Belliard, S., de la Sayette, V., Eustache, F., et. al. (2009). The underlying mechanisms of verbal fluency deficit in frontotemporal dementia and semantic dementia. Journal of Neurology, 256(7), 1083-1094.

Lee, J. H., Kang, K. H., Kwak, H. W., Chang, M. S., Bai, D. S., Park, S. P., et al. (2011). Usefulness of verbal fluency performance as follow-up screening tool in patients with mild to moderate Alzheimer's disease. Journal of the Korean Neurological Association, 29(2), 106-111.

Lukatela, K., Malloy, P., Jenkins, M., \& Cohen, R. (1998). The naming deficit in early Alzheimer's and vascular dementia. Neuropsychology, 12(4), 565-572.
Martin, A. \& Fedio, P. (1983). Word production and comprehension in Alzheimer's disease: the breakdown of semantic knowledge. Brain and Language, 19(1), 124-141.

Morris, J. C. (1993). The Clinical Dementia Rating (CDR): current version and scoring rules. Neurology, 43(11), 2412-2414.

Padovani, A., Di Piero, V., Bragoni, M., Lacoboni, M., Gualdi, G. F., \& Lenzi, G. L. (1995). Patterns of neuropsychological impairment in mild dementia: a comparison between Alzheimer's disease and multi-infarct dementia. Acta Neurologica Scandinavica, 92(6), 433-442.

Park, J. H. \& Kwon, Y. C. (1989). Part I : Development of the Test for the Elderly $=$ Korean Version of Mini-Mental State Examination (MMSEK). Journal of the Korean Neuropsychiatric Association, 28(1), 125-135.

Park, J. H. \& Kwon, Y. C. (1989). Standardization of Korean version of the Mini-Mental State Examination (MMSE-K) for use in the elderly. Part II. diagnostic validity. Journal of the Korean Neuropsychiatric Association, 28(3), 508-513.

Reed, B. R., Mungas, D. M., Kramer, J. H., Ellis, W., Vinters, H. V., Zarow, C., et al. (2007). Profiles of neuropsychological impairment in autopsydefined Alzheimer's disease and cerebrovascular disease. Brain, 130(Pt 3), 731-739.

Reisberg, B., Ferris, S. H., de Leon, M. J., \& Crook, T. (1982). The Global Deterioration Scale for assessment of primary degenerative dementia. The American Journal of Psychiatry, 139(9), 1136-1139.

Reiter, J. C. (2000). Measuring cognitive processes underlying picture naming in Alzheimer's and cerebrovascular dementia: A general processing tree approach. Journal of Clinical and Experimental Neuropsychology, 22(3), 351-369.

Román, G. C. (2005). Clinical forms of vascular dementia. In Paul, R. H., Cohen, R., Ott, B. R., \& Salloway, S. (1st ed.). Vascular Dementia: Cerebrovascular Mechanisms and Clinical Management (pp. 7-21). Totowa, NJ: Humana Press.

Snyder, L. S., Holland, A. L., \& Forbes, M. (1996). Lexical decisions in patients with Alzheimer's disease: some notes on automatic versus controlled processing. Journal of Communication Disorders, 29(5), 389-398; quiz 398-9.

Vogel, A., Gade, A., Stokholm, J., \& Waldemar, G. (2005). Semantic memory impairment in the earliest phases of Alzheimer's disease. Dementia and Geriatric Cognitive Disorders, 19(2-3), 75-81. 